\title{
Advance Levels of Pedagogy of Humanity Studies in Education
}

\author{
Vera N. Didenko ${ }^{1}$ \\ ${ }^{1}$ Smolensk State University; Smolensk, Russia \\ Correspondence: Vera N. Didenko, Smolensk, Smolensk State University, Russia.
}

Received: August 20, 2019

Accepted: December 7, 2019

Online Published: December 23, 2019

doi:10.5430/ijhe.v8n8p45

URL: https://doi.org/10.5430/ijhe.v8n8p45

\begin{abstract}
The goal of this study is to investigate the purposes of pioneers and describe their main achievements, who have worked on training methods of humanity. The article presents the scientific achievements of A.E. Kondratenkov in theoretical and practical pedagogy, among which a special role is given to the rural school as a kind of center for the spiritual revival of the village. The main attention in the article results is focused on the analysis of the contribution of A.E. Kondratenkov to practical humanistically oriented pedagogy, where the enduring values of the spiritual life of a person are humanized. The intrinsic value of human individuality is affirmed as well. As a novel strategy the methodological foundations of the pedagogical system of Kondratenkov and its essence are revealed. Finally, it is shown that the pedagogical activity of A.E. Kondratenkov deserves the research attention of scientists, educators, practitioners, and those who are concerned about the problems of the educational space of the modern school of Russia.
\end{abstract}

Keywords: effective humanism, human personality, methodological foundations, pedagogical heritage, pedagogy of humanity

\section{Introduction}

The goal of this study is to investigate the purposes of pioneers and describe their main achievements, who have worked on training methods of humanity. In this regard, first of all aims revealing the life-purpose professional credo of the original Smolensk teacher, corresponding member of the USSR Academy of Pedagogical Sciences, honored teacher of the Russian SFSR School, honored scientist of Russia, Professor A.E. Kondratenkov (1921-1992).

The article presents the scientific achievements of A.E. Kondratenkov in theoretical and practical pedagogy, among which a special role is given to the rural school as a kind of center for the spiritual revival of the village.

An important and fruitful period in the teaching activity of A.E. Kondratenkov was singled out, covering the 50s and 60s of the XX century, the time of his leadership of the Kobylkinskaya secondary school of the Khislavichi district of the Smolensk region and the Safonovskaya secondary experimental comprehensive boarding school of the Smolensk region, which became the basis for conducting scientific research by scientists of the Academy pedagogical sciences of the USSR, including A.E. Kondratenkov (Kondratenkov, 1973; 1975).

The main attention in the article is focused on the analysis of the contribution of A.E. Kondratenkov to practical humanistically oriented pedagogy, where the enduring values of the spiritual life of a person are humanized. The intrinsic value of human individuality is affirmed as well. The methodological foundations of the pedagogical system of Kondratenkov are revealed, its essence is revealed. A.E. Kondratenkov is presented as a tireless follower of the pedagogical ideas of A.S. Makarenko and V.A. Sukhomlinsky. It is shown that the pedagogical activity of A.E. Kondratenkov deserves the research attention of scientists, educators, practitioners, and those who are concerned about the problems of the educational space of the modern school of Russia (Calloway-Thomas, 2018; Freire, 2018).

According to the author, the viability of Kondratenkov's pedagogy can be traced on the example of the pedagogical activity of his former pupils from the Safonov boarding school, including Lyubov Aleksandrovna Batyuleva. Currently, Lyubov Aleksandrovna is the director of the Yartsevo boarding school for orphans and children left without parental care. The author of the article conducted a pedagogical interview with her. L.A. Batyuleva shared her memories of the time spent at the Safonovskaya boarding school, about the teacher and leader A.E. Kondratenkov, about his progressive pedagogical ideas tested by time and living pedagogical experience, about the pedagogy of humanism (Kondratenkov, 1979; 1985).

Department of Pedagogy and Psychology of Smolensk State University annually holds an international scientific and practical conference dedicated to the memory of an outstanding teacher, scientist-researcher, corresponding member of 
the USSR Academy of Pedagogical Sciences, Honored Teacher of the Russian SFSR School, Honored Scientist of Russia, Professor Alexander Erofeevich Kondratenkov. In October 2018, the XIII international scientific and practical conference dedicated to the memory of A.E. Kondratenkov was held. The conference ended with a "round table" in the format of a discussion platform on the topic "Didactics of a living example of A.E. Kondratenkov." The discussion was attended by teachers, students, undergraduates in the direction of preparation "Pedagogical education", graduate students of SmolSU. One of the important conclusions reached by the participants of the round table was the recognition of the didactics of the living example of A.E. Kondratenkov as a system that helps to identify the humanistic potential of a teacher as a professional and a citizen of his Fatherland (Compayré, 2015; Lingley, 2016; Slobodchikov, 2017: Sepehri \& Sheikhalizadeh, 2019).

\section{Methods}

This conclusion is confirmed by further research, during which are used:

\subsection{Theoretical Methods}

- $\quad$ study of philosophical, psychological, pedagogical sources;

- $\quad$ comparative historical method;

- $\quad$ retrospective analysis and synthesis of pedagogical phenomena;

- $\quad$ induction;

- $\quad$ deduction;

- $\quad$ concretism;

\subsection{Empirical Methods}

Experience generalization of advanced pedagogical practice of the 50-60s of the XX century on the example of pedagogical activity of A.E. Kondratenkov;

\subsection{Sociological Methods}

Pedagogical interviewing.

The main scientific achievements of A.E. Kondratenkov in theoretical and practical pedagogy are:

- Establishment of an organic unity of the general logic of cognition and transformation of sociocultural processes in the context of the development of a rural comprehensive school;

- Viability of the "didactics of a living example" as the methodological basis of the pedagogical system;

- Approbation of the humanistic, axiological, anthropological approaches in the pedagogical process of the rural school of Smolensk region;

- Installation on the education of a citizen and patriot as an urgent idea of education and upbringing;

- Affirmation of the intrinsic value of human individuality;

- Opening and implementation in the pedagogical process of the Kobylkinskaya secondary school of the Khislavichi district and the Safonovskaya secondary experimental comprehensive boarding school "the law of faith of a collective of people united into a single whole common cause";

- Demonstration of ways to effectively resolve pedagogical situations on the basis of the principle of complexity ("nursery" - "kindergarten" - "school") in the activities of the Safonovskaya secondary experimental comprehensive boarding school;

- Actualization of the need to appeal to the idea of considering rural schools as unique centers of spiritual revival of the village;

- Identification of the symptom complex of youth readiness for active work in rural areas;

- Effective pedagogical management of the labor activity of pupils with the recognition of labor as the most important factor in the socialization of the individual;

- Harmonization of the activity ties of the rural comprehensive school for the labor education of schoolchildren with the daily tasks of developing local agricultural production;

- Transformation of rural school collectives into adult-child communities with the potential of humanity;

- Establishing close contact between teachers and families of students, identifying the best traditions of the family; 
- Effectiveness of the optimization of the educational process of the rural school;

- Introducing into the pedagogical process of the rural school progressive ideas of greening the relationship "man nature - society";

- Introduction to school life "extended day mode";

- Organization of student production teams and units, school facilities;

- Acquisition of teams of different ages based on rural schools;

- Creation of advanced pedagogical experience and attracting to it a posteriori of the pedagogical community of domestic and foreign schools, etc.

\section{Results and Discussion}

The pedagogical heritage of A.E. Kondratenkov includes the books "Do not forget about your duty", "Notes of the school principal", "Rural comprehensive school at the present stage", "Work and talent of the teacher", "Pedagogy in the pictures of real life", etc., as well as numerous articles. It is possible to evaluate the contribution of A.E. Kondratenkov to the domestic pedagogy of today only by including his pedagogical heritage in the modern educational context, his sociocultural and spatiotemporal conditions (Kaufman, 2017).

A.E. Kondratenkov became known in the pedagogical environment as a teacher-researcher during the years of leadership of the country's first scientific laboratory on the problems of a rural school at the USSR Academy of Pedagogical Sciences. This was the time of his teaching activity at the Smolensk Pedagogical Institute. The problem laboratory became the coordinator of joint research activities of teams of pedagogical universities in Bashkiria, Belarus, Dagestan, Kyrgyzstan, Kazakhstan, and Ukraine in the 70s of the twentieth century. According to the results of scientific research, more than 30 collections of scientific works of scientists were published. The activity of Professor A. E. Kondratenkov as head of the Department of Pedagogy at the State Pedagogical Institute, Vice-Rector for Academic Affairs, Vice-Rector for Academic Affairs, and Head of Graduate Students was fruitful. Under his leadership, 38 master's theses were defended in the specialty 13.00.01 (general pedagogy, the history of pedagogy and education).

However, in our opinion, A.E. Kondratenkov showed himself most vividly as a teacher-practitioner in the 50-60s of the XX century. Let us turn to the historical period of Russian pedagogy in the middle of the twentieth century, in which the human history character of the teaching and managerial activity of A.E. Kondratenkov and his civic-patriotic position were captured. Alexander Erofeevich began his career as a teacher of literature of a rural school in the Smolensk region. The teaching profession was truly his calling. And becoming the director of the Kobylkinskaya secondary school of the Khislavichi district, and then the head of the country's first and largest Safonovskaya secondary experimental comprehensive boarding school, A.E. Kondratenkov remained a teacher. After three years of his leadership of the school in Kobylkin, she became the initiator of many interesting things that have found distribution in the region and beyond. The uniqueness of the managerial style of A.E. Kondratenkov was revealed with renewed vigor during the years of his management of the Safonov boarding school. The advanced pedagogical experience of the boarding school attracted the attention of teachers, psychologists, and heads of educational institutions not only in our country, but also abroad (Ma'arif, 2018).

We single out the features of the period under review, which are reflected in the professional-value orientations and priorities of the teaching staff of Kondratenkov. These include: labor enthusiasm, which swept the country after victory in the Great Patriotic War; society's need for respect for domestic traditions; the growth of the spiritual and moral self-awareness of the people; recognition as fundamental values of freedom, justice, patriotism, professional responsibility, etc. (Didenko, 2016).

Transformations in economics and politics, public life and science have generated interest in the issues of humanization in the field of education. The idea of a comprehensive and harmoniously developed personality as the goal of education was proclaimed. A. E. Kondratenkov considered it as the main purpose of man; the ideal sought by his teaching staff; general education strategy in the pedagogical system of the Safonovo boarding school.

A.E. Kondratenkov deeply comprehended the new trends that arose in pedagogical science. Education and upbringing presented to him as a personally and professionally significant sociocultural value, enriched by the ideas of dialogue, cooperation, and respect for the individual, attitude to a person as a subject of knowledge, communication and creativity. On the fertile ground of the humanistic approach, the students of the boarding school were involved in the socially necessary, conscious, constructive work, which Alexander Erofeevich considered as an important factor in the socialization of the individual. Through the familiarization of the pupils with the work, labor and cultural life of the 
country and the small Motherland, its historical experience, ideals and traditions of society, the emotional-value attitude of students to the world, their historical memory, and most important human qualities were formed.

It should be noted that Alexander Erofeevich was a man of knowledge. He was always interested in "significant others" - teachers, foster children, parents of foster children and their human destinies. Kondratenkov's keen interest in the individuality of school teachers and students is reflected in the content of the pedagogical essays of his books "Pedagogy in Pictures of Real Life" and their titles: "Writer Stolyarov", "Educator Nikolai Romanovich", "Director Levitin", "Head of Annovskaya Primary", "In the classes of Stepan Sergeyevich", "Seryozha Gorkin", "Ships of our Vitya", "Tolya and His Brothers", and others, Alexander Erofeevich proceeded from the assumption that each person is valuable and unique.

The methodological basis of the pedagogical system of A.E. Kondratenkov is "the didactics of true life, a living example." It comes to life meaningfully in phrases: living word, lively interest, lively knowledge, lively perception, lively communication, lively process, lively pedagogical experience, repeatedly broadcast in various contexts on the pages of A.E. Kondratenkov's books. The essence of the didactics of a living example is that it frees the teacher from the obligation to follow the imperative to impose a theoretical scheme on the real practice of an exceptionally complex and diverse school life.

The work of the teacher is considered by Kondratenkov as a creative process, which is not peculiar to abstract prescriptions and pre-formulated conclusions. Numerous situations of the living pedagogical process, presented in the pedagogical heritage of the author, make it possible to comprehend and analyze the various manifestations of the actions of the actors, their intentions, goals, ways of resolving contradictions, and ways of understanding the laws of the educational process (Hashemian \& Farhang-Ju, 2018).

Deep methodological foundation, proclaimed by Kondratenkov's pedagogy, contributed to the emergence of dialogical interactions between all the real participants in the pedagogical process. Among them in the thick of things is the teacher Kondratenkov himself. Therefore, he, along with everyone thinks, ponders, calls to take part in discussions of problem situations, peculiarly materializing them in time and space of the 50-60s of the XX century. At the same time, this model of didactics of a living example should be supplemented by pedagogical conditions identified by us in the course of comprehending its essence and structure:

1) Adoption by teachers of the school installation on the humanization of the education system in their own motivational sphere, inner world, self-awareness;

2) Presence of creative dominance of pedagogical collectives on the formation of effective humanism in the educational space of a rural school;

3) Design and creation of holistic images of the dyad "teacher - creator", "pupil - creator" in the pedagogical process of the school;

4) Stimulation of joy in situations of interaction between teachers and pupils;

5) Professional responsibility of teachers for the fate of children.

The pedagogical discoveries of Alexander Erofeevich, his individual touches on his personality, flexible methods of interaction with teachers, children's groups, and parents of students went down in the history of pedagogy as examples of a truly human attitude to colleagues and pupils. In this process, a personal-professional image was formed, a professional credo of the very head of the teaching staff - Alexander Yerofeyevich Kondratenkov. Their unity can be defined by the philosophical thought of A.F. Losev as a practice of serving "universal human prosperity" (Losev, 2019). The humane meaning inherent in his school management system united the entire child-adult community and contributed to the emergence of effective humanism. In the activities of Director Kondratenkov, the principle came to life: "as much as possible requirements for a person and as much as possible respect for him" as told by A. S. Makarenko. This principle contains a powerful motivational force that stimulated the awakening of self-esteem in children, the manifestation of their best moral qualities.

Being a tireless follower of the humanistic pedagogical ideas of V.A. Sukhomlinsky, A.E. Kondratenkov develops his well-known idea that "every child is a completely special, unique world". So, the development of individuality from the "collective subject" acts as one of the leading principles of the Safonovo boarding school. Its implementation was carried out on the basis of the installation on the harmonious development of all areas of the personality of the pupil. The humanistic motive of pedagogy Kondratenkov was expressed in faith in the strength and ability of each child, in a good beginning in him. "To safeguard the honor and dignity of each pet and to certainly teach everyone this is the highest of all the tasks of our educational institution," wrote A.E. Kondratenkov (Kondratenkov, 1993). And in the 
light of this humanistic thesis, the eternal values of the spiritual life of a person as self-value of a higher order are humanized. The essays of the book "Pedagogy in Pictures of Real Life" confirm the importance of this super-task for the teaching staff of the boarding school. Teachers worked without sparing themselves, did not rest for days. All the more joyful they met every achievement - in organizing children's self-government, in establishing studies and in establishing the regime of the day, working together with colleagues and pupils, joint trips and school evenings, trips on excursions. Here is just a small list of Director Kondratenkov's daily worries.

In the collective sense of joy, fullness of life, unity, a peculiar law revealed by the teacher manifested itself - "the law of the faith of a collective of people united into one whole by a single common cause."

\subsection{Results Summery}

1. The uniqueness of A.E. Kondratenkov as an outstanding teacher of the successor of ideas A. S. Makarenko and V.A. Sukhomlinsky is revealed.

2. A retrospective analysis of the sociocultural situation of the 50-60s of the twentieth century is presented and its influence on the origin of the pedagogy of humanity by A.E. Kondratenkov is shown.

3. The human history character of the teaching and managerial activity of A.E. Kondratenkov is revealed.

4. The content of the didactics of a living example as a methodological basis of the pedagogical system of A.E. Kondratenkov is disclosed.

5. The pedagogical conditions for the implementation of the didactics model of a living example in the pedagogical process of the schools of Smolensk region led by Kondratenkov are determined.

6. The emphasis is made on the essence and content of the professional life credo of the teacher Kondratenkov.

7. The relevance of the pedagogy of humanity by A.E. Kondratenkov in the modern educational space of the Russian school is shown.

\section{Conclusion}

The pedagogical work of Alexander Erofeevich Kondratenkov was recognized in our country and abroad during his lifetime. The pedagogical heritage is significant today for practicing teachers, heads of educational institutions, parents of students. The life-professional credo of the teacher Kondratenkov is surprisingly manifested in his main life-giving quality, whose name is "humanity". The human-scientific searches and finds of the teacher A.E. Kondratenkov are still relevant for modern pedagogical theory and practice. Let us refer to the point of view of V. I. Slobodchikov regarding the model of a new national education in the 21 st century. "Humanity", in the scientist's assessment, as an absolute resource of the cultural and historical development of society, is becoming the subject of close attention of the progressive pedagogical community. So, in modern conditions, a fundamentally new humanitarian-anthropological dimension of education appears as evidence of the need for a person to ascend to the fullness of his own reality. In our opinion, a lively, constructive thought, embedded in the value-semantic space of the pedagogical heritage of A.E. Kondratenkov, reflecting the pedagogical reality of rural schools, can bring real benefits in determining the strategy and tactics of a new model of national education in the 21st century. Nevertheless, years later of the books of Alexander Yerofeyevich Kondratenkov, an interested reader will discover for himself, whose true purpose is the teaching, who will attract a deep and happy country - the pedagogy of humanity of A.E. Kondratenkov.

\section{References}

Calloway-Thomas, C. (2018). A call for a pedagogy of empathy. Communication Education Journal, 67(4), 495-499. https://doi.org/10.1080/03634523.2018.1504977

Compayré, G. (2015). The history of pedagogy. Abingdon: UK, Routledge Publishing. https://doi.org/10.4324/9781315650449

Didenko, V. N. (2016). Civil-patriotic heritage of A.E. Kondratenkov. Teacher and time: Eleventh pedagogical readings dedicated to the memory of A.E. Kondratenkov. Smolensk: Russia, Publishing House of SmolGU (Smolensk State University).

Freire, P. (2018). Pedagogy of the oppressed. Bloomsbury publishing USA.https://doi.org/10.4324/9780429269400-8

Hashemian, M., \& Farhang-Ju, M. (2018). Effects of Metalinguistic Feedback on Grammatical Accuracy of Iranian Field (In) dependent L2 Learners' Writing Ability. Research in Applied Linguistics, 9(2), 141-161.

Kaufman, P. (2017). Critical contemplative pedagogy. Radical Pedagogy Journal, 14(1), 1-20. 
Kondratenkov A. E. (1973). Do not forget about your duty. Smolensk: Russia, "Moskovskiy Rabochiy" Publishing House.

Kondratenkov A. E. (1975). Notes of the school principal. Moscow: Russia, Pedagogy Publications.

Kondratenkov A. E. (1979). Rural comprehensive school at the present stage. (Issues of labor education of students). Moscow: Russia, Pedagogy Publications.

Kondratenkov A. E. (1985). Labor and talent of a teacher: Meetings. Data. Thoughts: Prince For the teacher. Moscow: Russia, Education Publications.

Kondratenkov A. E. (1993). Pedagogy in the pictures of real life. Smolensk: Russia, Smyadyn Publications.

Lingley, A. (2016). Democratic foundations for spiritually responsive pedagogy. Democracy and Education Journal, 24(2), 1-6.

Losev, A. F. (2019). On the credo of life. Theoretical journal of Credo, URL: credonew.ru>content/view/452/57 (accessed: 07/05/2019).

Ma'arif, S. (2018). Education as a Foundation of Humanity: Learning from the Pedagogy of Pesantren in Indonesia. Journal of Social Studies Education Research, 9(2), 104-123.

Sepehri, Z., \& Sheikhalizadeh, M. (2019). Descriptions and overall safety status of sport fields in schools of Ardabil city, Iran. UCT Journal of Social Sciences and Humanities Research, 7(02), 1-5.

Slobodchikov, V. I. (2017). Domestic education in the XXI century: a new image. Pedagogical education and science, 2, 36-37. 